PRIMANOMICS : JURNAL EKONOMI DAN BISNIS - VOL. 19. No. 1 (2021)

Versi Online Tersedia di : https://jurnal.ubd.ac.id/index.php/ds

| 1412-632X (Cetak) | 2614-6789 (Online) |

\title{
Impact of Corporate Culture, Division of Labour, Organizational Structure Toward Job Performance PT. XYZ
}

\author{
Raston Sitio 1 ) \\ rastonsitio65@gmail.com \\ Charles V Sianipar ${ }^{2)}$ \\ charles.sianipar57@gmail.com \\ Rodeyar Pasaribu3) \\ rodeyar_pasaribu@yahoo.com \\ Parel Naibaho4) \\ parelmnaibaho@gmail.com \\ Dessy Marhandrie ${ }^{5}$ \\ dessy.stia@gmail.com \\ 1) 2) 3) 4) 5)Fakultas Ekonomi Universitas Mpu Tantular
}

\begin{abstract}
The urgency of this research was to get the impact of corporate culture, division of labour and organizational structure toward employee job performance of PT. XYZ. This study will get variables which have the most dominant influence on job performance. The study used primary data obtained directly from respondents. The technique of collecting data used questionnaires that distributed to 124 respondents who were selected to be the research samples from 179 population of PT. XYZ employees using the Slovin formula, the margin of error is $5 \%$ with a Likert scale. The data is processed and tabulated. The stages of this research are concept analysis, literature study, distribution of questionnaires, tabulation then analyzed. The technique of data analysis is linear multiple regression with data processing using SPSS. The study conducted four months starting from June to October 2020 at the PT. XYZ Company which is located in West Jakarta. The scale used in the questionnaire is a Likert scale. The results of this study show that the relationship between corporate culture, division of labour and organizational structure at PT. XYZ is not too significant for job performance. The impact is very varied, namely, the influence of corporate culture is quite significant, it is in contrast the impact caused by the division of labour and organizational structure which is very insignificant.
\end{abstract}

Keywords: corporate culture, Division of Labour, Organizational Structure, Job Performance 


\section{INTRODUCTION}

Today, the advancement of a corporate is closely related to the behaviour of every member of the organization involved in work. Good behaviour and attitudes will greatly contribute to increasing achievement and performance. According to Basid, Rezqi and Ananada (2020), there are in-role behaviours and extra-role behaviour is the difference in employee work behaviour in the Organizational Citizenship Behavior, it is referred to as OCB (Basid, Rezqi and Ananda, 2020). Attitudes and behaviour are part of a person's culture which are inherently visible from how to act in achieving job performance. Job performance will be achieved with the same vision and goals. According to Kusumawardani (2018) that organizational culture is a set of assumptions or belief systems, values and norms developed in the organization that serve as guidelines for behaviour for its members to overcome problems of external adaptation and internal integration. Company culture is difficult to define explicitly and difficult to measure, but it can be felt by employees in the company (Atmosoeprapto, 2001). Company organizations are composed of organs that include various parts that work together to carry out each activity. Organizations are formed from a collection of different individuals both in nature, character, expertise, education and background experience in life, it is necessary to recognize views that are useful for the achievement of the organization mission. It is useful so that the behaviour of organizational members is in line with the role models of company leaders. According to Usdarisman and Erpidawati (2020) that leaders who can manage and direct organizational members are leaders who have charisma, are respected, and role models for their employee. Organizational culture can help employee performance because it creates an extraordinary level of motivation for employees to give their best ability and they take advantage of the opportunities provided by the organization (Salam et al., 2017). Corporate culture contains a system of shared meaning that is shared by each member to distinguish each member of the organization. In addition to cultural factors in supporting job performance, a clear division of work will support the achievement of better corporate performance. In achieving corporate performance, the employee's performance must be improved. Roring (2017) states that improving employee performance requires the quality of human resources. One of the factors affecting the increase in human resources is the difference in the results of work using the principle of division of labour. It becomes important for the company. Companies can make groups of types of work so that the level of efficiency and effectiveness can be done. In other words, the level of effectiveness and efficiency have an impact on corporate performance which will give the acceleration in both productivity and management. A good organizational culture and labour division is useless if the creation of the company's organizational structure is not by the shape and character of the company. Therefore, companies need an appropriate strategy in creating a simple organizational structure but it can organize all members of the company. According to Bernardin and Russel (2002), job performance is the level of success achieved by a person to determine the extent to which a person completes the assigned tasks and responsibilities. Every company has an assessment or measurement so that the results of each performance can be known.

\section{Identification of Problems}

Based on the background of the problems described above, the identification of problems in this study are as follows:

a. There is a problem of corporate culture on employees' job performance at PT.XYZ. 
PRIMANOMICS : JURNAL EKONOMI DAN BISNIS - VOL. 19. No. 1 (2021)

Versi Online Tersedia di : https://jurnal.ubd.ac.id/index.php/ds

| 1412-632X (Cetak) | 2614-6789 (Online) |

b. There is a problem with the division of labour on employees' job performance at PT. XYZ.

c. There is a problem of organizational structure on employees' job performance at PT. XYZ.

\section{LITERATUR REVIEW}

\section{Definition of Corporate Culture}

Every individual has different characteristics as a character for a person so that everyone can know his nature. Likewise, organizations have certain characteristics that are known as organizational culture (Novziransyah, 2017). Culture is values, ideas, attitudes, and other symbols that are complex and meaningful and serve humans to communicate, interpret and evaluate employees. Trang (2013) states that organizational culture is institutionalized values, assumptions, attitudes and behavioural norms, then it is manifest in appearance, attitudes and actions so that it becomes the identity of a particular organization. Due to the unique nature of the organization, the organizational culture in the company must be the glue for each member of the organization as well as a differentiator from other companies. The same opinion is from Hakim, L., Kusdiyanto (2012) that culture is derived from the word culture adapted from Latin, namely cult which means inhabiting, working, or worshipping, and are which means the result of something. From this definition, the meaning of culture is obtained, namely doing something that comes from something. Organizational culture is not only a differentiator, but it can also be made into motivation for employees. As stated by Hayati (2020), organizational culture can be used as a reference for employees in assessing the amount of achievement of goals from the performance. Every organization has a different culture and each has a philosophy that is by its business principles, ways of solving problems and making their own decisions, and has their own beliefs, behaviours and patterns of thinking, business practices and personalities (Wahyudi., Tupti, 2019). The function of organizational culture in the company is very large in improving the performance of employees and the company. As stated by Salam, et.al (2017) that organizational culture has a contribution in shaping employee behaviour such as instilling values and attitudes of employees in achieving organizational goals. Organizations can operate when there are shared values. These values will guide his behaviour in every treatment process throughout his activities. Maintenance is an activity to maintain facilities or equipment and make repairs or replacement adjustments needed so that they can be used properly (Sitio., Marhandrie, 2020). Job culture is a shared value or principle in an organization and is used as a guide in action (Vilani., Murtini., Subarno, 2019). In acting, it must be based on a complete understanding so that the achievement of goals can be maximized. According to Denok and Sunarsi (2019), a culture is several important understandings such as norms, values, attitudes, and beliefs that are shared by organizational members. Although there is no strong definition of corporate organizational culture, an interpretation can be made according to one's experience. As stated by Atmosoeprapto (2001), company culture or job culture is difficult to define clearly and is difficult to measure, but it can be felt by employees in the company. Because an organization is formed from a collection of individuals with different characteristics, characters, skills, education and experience backgrounds in life, it is necessary to have a unified view that is used to achieve the company's mission. 


\section{The Division of Labour}

The division of labour is a grouping of the types of work assigned to employees and adjusted to the capabilities of each employee to achieve maximum organizational goals. In addition to the division of labour, discipline, training in the tools used can assist employees in carrying out their duties Humans who do it must be trained to be skilled in using the tools with high discipline (Sitio, 2019). In good management, the division of labour must be carried out appropriately, clear delegation of authority and good coordination so that the achievement of company goals can be realized properly (Pangastuti., Sigit. ., Nurhasan. 2013). In the division of labour, every member of the organization is disciplined so that every task assigned to each employee can be carried out properly. When placing a person in the division of labour chart, you must pay attention to many things to be right on target. According to Kusumawardani \& Laksmi (2018) that different types of work, level of position, educational background, family status, and another social status will underlie differences in managing employees. Indicators in work grouping must pay attention to various dimensions as stated by Hadian (2015) that the departmentalization dimension uses basic indicators of grouping work according to functions carried out and the same level of task coordination, while the chain of command dimension uses indicators of the level of authority and the level of command unity.

\section{Organizational Structure}

The organizational structure of the company describes the wide range of parallel and crossfunctional coordination of functions, as well as the length of the range of command levels from the highest leadership to the supervisory level. This structure also shows the extent of the scope of the company's activities. According to Handoko (2002) that organizational structure is the relationship between employees and their activities with each other as well as to the whole, where the parts are tasks, jobs or functions and each member of the employee group who carries it out. Thus, every member of the company organization must understand the forms of organizational structure so that the implementation is by the character and business objectives of the company. Hamiddan Riza (2014) states that studying organizational structure can find out what possible activities are in an organization because the parts in an organization are drawn with the names and positions of each level of leadership, duties and responsibilities. The form of the company's organizational structure must be able to clearly describe the operational conditions and the relationship of the company's activities, where there is a separation of work activities from one another and their functions. Jones and George (2007) state that four factors affect organizational structure, namely, first, the company's organizational environment is constantly adapting to environmental changes, second is implementing strategy effectively, third is combined expertise, knowledge and equipment to produce and distribute goods and services, and the fourth is the role of human resources with characteristics that match the job in the company.

\section{Employee Job Performance}

All employees in the company must always reach the target sizes that have been given by the company. Maximum work results can not only be produced by individuals but must be driven by business factors and the abilities and opportunities that employees have (Sitio, 2020). Every member of the organization must be allowed to show his expertise to motivate each employee. According to Mangkunegara (2000) work performance is the result of quality work achieved by someone in carrying out their duties according to the 
responsibilities given to them. Not all employees in the company have the same skills and intelligence, this is influenced by their educational background and expertise. Psychologically, the ability of employees consists of potential abilities (Intelligence Quotient) and reality abilities (knowledge + skills), it means that employees who have an Intelligence Quotient above Average (110-120) with adequate education for his position and skilled in doing daily work, it will be easier to achieve the expected performance (Sulastri, 2007). The rationale for the need for Total Quality Management (TQM) is the best way to compete and excel in the global competition which is by producing the best quality. To produce the best quality in competition, continuous improvement efforts are needed (Tae, A, M., Rahmat, L., Muhram, 2019). Other factors needed by every member of the company organization to achieve job performance is to be responsive to changes both within the company and outside the company environment. Thea Herawati R., (2017) said that the ability of organizations to respond to the changing of life must be better, this is the basis for facing competition in the information period. Many factors affect job performance that must be considered by companies. According to Supardi and Mangkunegara (2006), the factors that affect job performance include quality of work, the quantity of work, knowledge of job adjustments, work relations, and work initiatives. All work carried out by all members of the company organization must be made a clear measure of the level of achievement. According to Wayne Mondy (2008) argues that the main purpose of a performance appraisal system is to improve individual and organizational performance. So that the benefits can be felt by the company.

\section{Framework of thinking}

Independent Variable

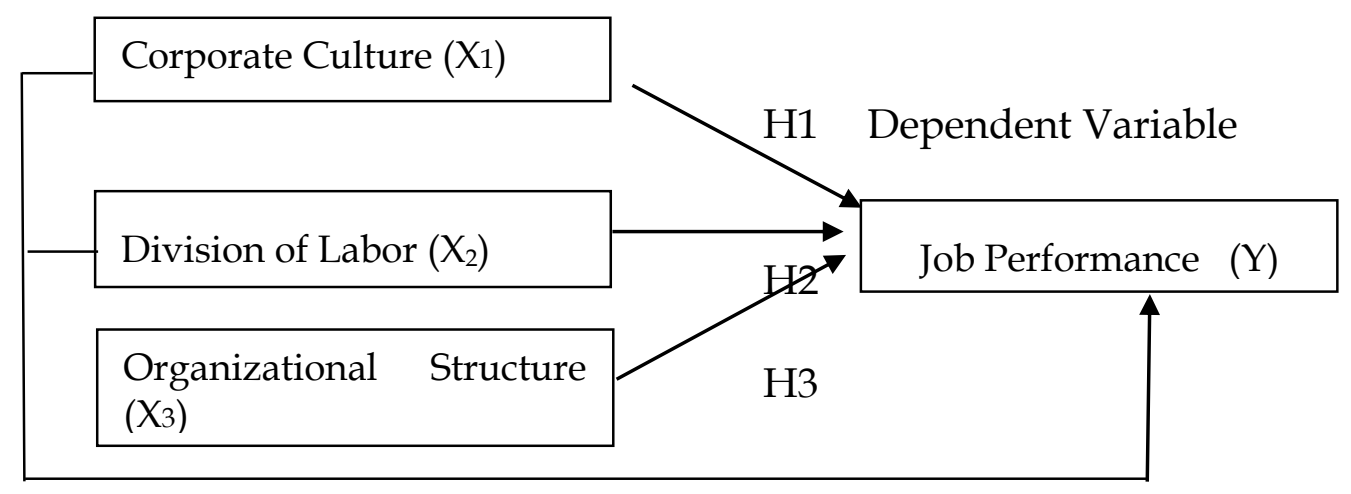

Source: Processed Data

Figure 1. Framework of Thinking

\section{RESEARCH METHOD}

The research used correlation descriptive method to explain the relationship and influence of the independent variable on the dependent variable. This research was conducted from July to October 2020 at PT. XYZ. Sugiyono (2014) stated that correlation descriptive research is a quantitative approach to explain and describe each variable by using data in the form of numbers, then explaining the relationship between the two variables. 


\section{Population and Sample}

The population of this study consisted of 179 employees at PT. XYZ using the Slovin technique with a DF of $95 \%$ or a margin of error of $5 \%$, a sample of 124 respondents was obtained.

$$
\begin{aligned}
& \mathrm{n}=\frac{N}{1+N e^{2}}=\mathrm{n}=\frac{179}{1+179 \times 0.05^{2}}=124 \\
& \mathrm{n}=\text { Sample } \\
& \mathrm{N}=\text { Population } \\
& \mathrm{e}=\text { Percentage of allowance or inaccuracy values due to sampling error }
\end{aligned}
$$

\section{Data Collection Technique}

The data collection technique in this study was carried out by distributing questionnaires to 124 PT. XYZ employees who became respondents using a Likert scale, giving a gradation score from very positive to very negative, namely; Strongly Agree (SA) was given a score of 5, Agree (A) was given a score of 4, Doubt (DD) was given a score of 3, Disagree (D) was given a score of 2, Strongly Disagree (SD) was given a score of 1 . (Umar, 2008)

\section{Technique of Testing}

Questionnaires data test and models in the study were conducted to determine whether all the requirements were fulfilled so that it could be continued in regression analysis. Reliability test is carried out for a questionnaire which is an indicator of a variable or constructs towards a person's answer to a statement whether it is consistent over time. It is said to be realistic if the Cronbach Alpha value is greater than 0.6. A valid questionnaire can be measured and can reveal a questionnaire that will be measured by the questionnaire. The measurement uses the product-moment correlation value $(r)$ if $r$-count $>r$-table, then the indicator used is valid or vice versa. The heteroscedasticity test was carried out to test whether the regression model used was inequality of variance from one residual observation to another. A good regression model is a heteroscedasticity does not occur by looking at the Scatterplot graph between the predicted values of the dependent variable and its residuals. The normality test is used to determine whether in the regression model the confounding variable has a normal distribution by looking at the distribution of points on the P-P Plot of Regression Standardized Residual graph. The multicollinearity test was used to determine whether the regression model found a correlation between the independent variable and the dependent variable. A good model if there is no correlation by looking at the variance inflation factor (VIF) value (Ghozali, 2012)

The technique of Data Analysis

Linear multiple regression is used to measure the effect of more than one independent variable on the dependent variable with a mathematical equation: $Y=a+b 1 X 1+b 2 X 2+$ b3X 3. Then to determine the effect of the variable partially, it is done by testing the determination by looking the value of the determination coefficient (DC) with the test formula Partial (t-test), statistical F-test (Sugiyono, 2012)

\section{RESULTS AND DISCUSSION}

Validity Test

Table 1. The Result of Variabel Validity Test 
PRIMANOMICS : JURNAL EKONOMI DAN BISNIS - VOL. 19. No. 1 (2021)

Versi Online Tersedia di : https://jurnal.ubd.ac.id/index.php/ds | 1412-632X (Cetak) | 2614-6789 (Online) |

\begin{tabular}{|c|c|c|c|c|c|c|}
\hline Item & All & $\begin{array}{l}\text { Corporate } \\
\text { Culture }\end{array}$ & $\begin{array}{l}\text { Division } \\
\text { of Labor }\end{array}$ & $\begin{array}{l}\text { Organizational } \\
\text { Structure }\end{array}$ & $\begin{array}{l}\text { Job } \\
\text { Performance }\end{array}$ & Conclusion \\
\hline & r critical & r count & r count & r count & r count & All \\
\hline $\mathrm{X}_{1.1}$ & 0,30 & 0,735 & 0,325 & 0,706 & 0,479 & Valid \\
\hline $\mathrm{X}_{1.2}$ & 0,30 & 0,536 & 0,514 & 0,476 & 0,509 & Valid \\
\hline $\mathrm{X}_{1.3}$ & 0,30 & 0,359 & 0,423 & 0,719 & 0,695 & Valid \\
\hline $\mathrm{X}_{1.4}$ & 0,30 & 0,724 & 0,685 & 0,733 & 0,545 & Valid \\
\hline $\mathrm{X}_{1.5}$ & 0,30 & 0,305 & 0,737 & 0,681 & 0,419 & Valid \\
\hline $\mathrm{X}_{1.6}$ & 0,30 & 0,562 & 0,680 & 0,719 & 0,653 & Valid \\
\hline $\mathrm{X}_{1.7}$ & 0,30 & 0,490 & 0,313 & 0,436 & 0,537 & Valid \\
\hline $\mathrm{X}_{1.8}$ & 0,30 & 0,724 & 0,481 & 0,455 & 0,695 & Valid \\
\hline $\mathrm{X}_{1.9}$ & 0,30 & 0,473 & 0,685 & 0,733 & 0,545 & Valid \\
\hline $\mathrm{X}_{1.10}$ & 0,30 & 0,621 & 0,680 & 0,318 & 0,653 & Valid \\
\hline
\end{tabular}

Source: processed data

Table 1 shows that the test results for all variables obtained $r$ count $>r$ critical, which is the average above 0.30 , thus all items or variables are valid.

\section{Reliability Test}

Table 2. Reliability Test Results

\begin{tabular}{|l|c|c|}
\hline \multicolumn{1}{|c|}{ Variable } & Alpha & Conclusion \\
\hline Corporate Culture & 0,651 & Reliabel \\
\hline Division of Labor & 0,706 & Reliabel \\
\hline Organizational Structure & 0,632 & Reliabel \\
\hline Job Performance & 0,684 & Reliable \\
\hline
\end{tabular}

Source: processed data

Table 2 shows the results of the reliability test of all variables, the results are above the required Cronbach's alpha coefficient, namely 0.60, thus all questionnaires are reliable.

\section{Normality Test}

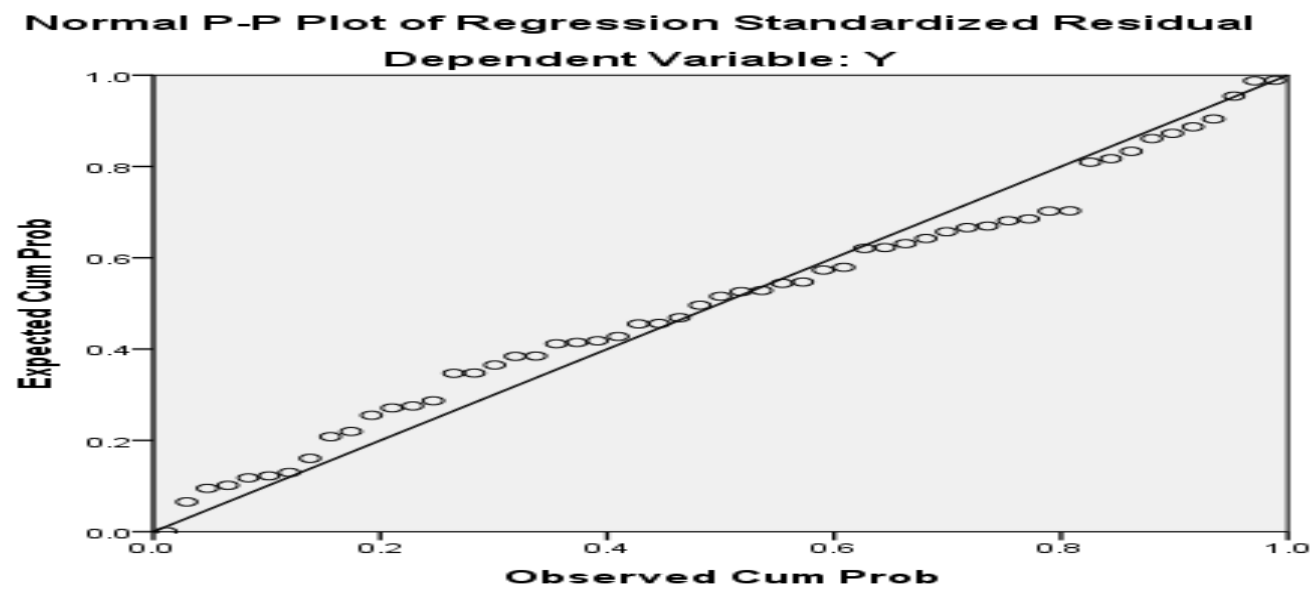

Source: processed data

Figure 1. Normality Test Results 
Figure 1. is seen in the normal graph. The plot shows the dots spread around the diagonal line, and the spread follows the direction of the diagonal line. Both graphs show that the regression model is feasible because it meets the assumption of normality.

\section{Multicollinearity Test}

Table 3. Multicollinearity Test

\begin{tabular}{|l|c|c|}
\hline \multirow{2}{*}{ Model } & \multicolumn{2}{|c|}{ Collinearity Statistics } \\
\cline { 2 - 3 } & Tolerance & VIF \\
\hline Corporate Culture & 0,891 & 1.122 \\
\hline Division of Labor & 0,992 & 1.008 \\
\hline $\begin{array}{l}\text { Organizational } \\
\text { Structure }\end{array}$ & 0,893 & 1.119 \\
\hline
\end{tabular}

Source: processed data

Table 3 shows the multicollinearity test results, the tolerance value $<0.10$ and the VIF value $>$ 10 , so it can be concluded that there is no multicollinearity between the independent variables in the regression model.

\section{Heteroscedasticity Test}

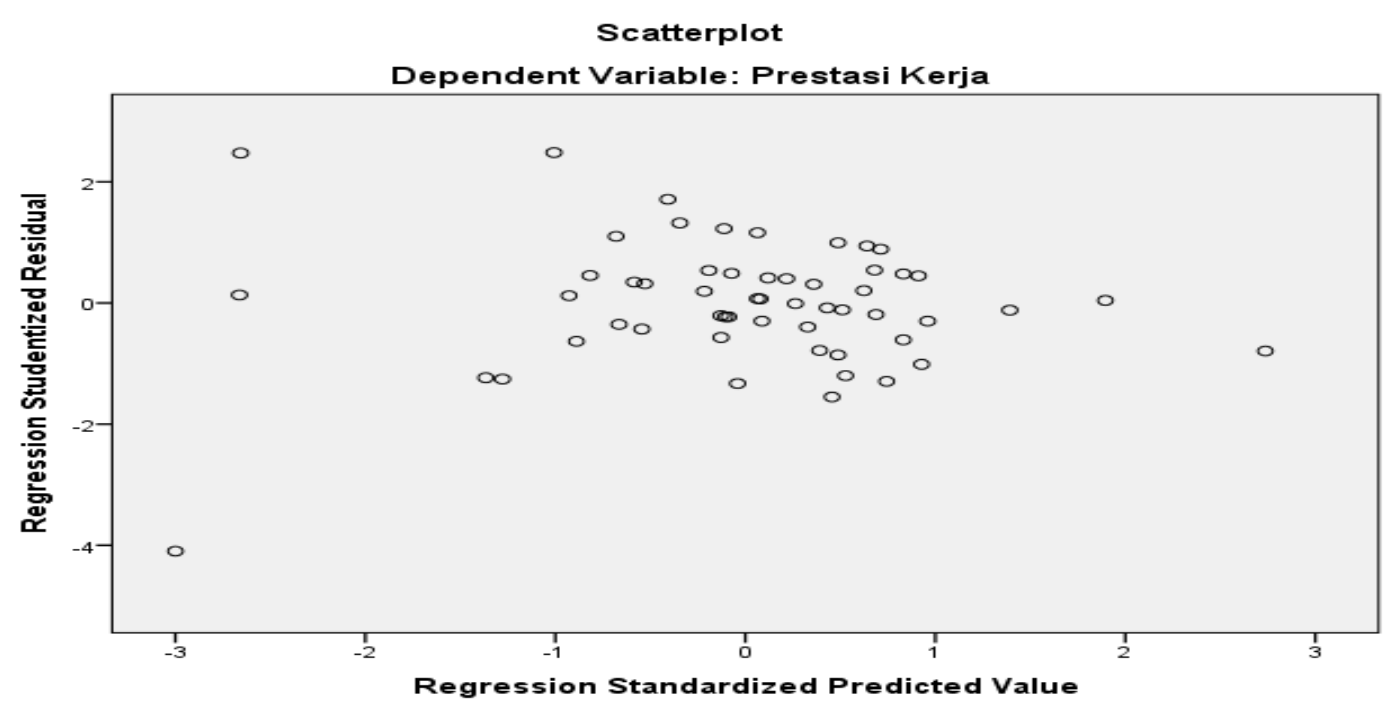

Source: processed data

Figure 2. Heteroscedasticity Test Results

Figure 2. can be seen that the dots spread randomly and are evenly distributed above and below the number 0 on the $Y$-axis and do not have a clear pattern or do not form a pattern. For this reason, it can be concluded that there is no heteroscedasticity in the regression model, so the regression model is suitable to be used as a prediction.

\section{Determination Coefficient Test}

Table 5. Results of the Determination Coefficient 
PRIMANOMICS : JURNAL EKONOMI DAN BISNIS - VOL. 19. No. 1 (2021)

Versi Online Tersedia di : https://jurnal.ubd.ac.id/index.php/ds

| 1412-632X (Cetak) | 2614-6789 (Online) |

\begin{tabular}{|c|c|c|c|c|}
\hline \multicolumn{4}{|c|}{ Model Summary } \\
\hline Model & R & R Square & Adjusted R Square & Std. The error of the Estimate \\
\hline 1 & 0.546 & 0.340 & 0.120 & 1.710 \\
\hline
\end{tabular}

Source: processed data

Table 5. shows the results of $\mathrm{R}=0.546$. This means that the independent variable can be a predictor of the dependent variable by $54.6 \%$ and the remaining $45.4 \%$ is influenced by other factors that have not been studied.

\section{Multiple Regression Analysis}

Table 6. The Result Test of Multiple Regression Analysis

\begin{tabular}{|c|c|c|c|c|c|c|}
\hline \multicolumn{7}{|c|}{ Coefficients } \\
\hline & \multirow[t]{2}{*}{ Model } & \multicolumn{2}{|c|}{$\begin{array}{c}\text { Unstandardized } \\
\text { Coefficients }\end{array}$} & \multirow{2}{*}{$\begin{array}{c}\begin{array}{c}\text { Standardized } \\
\text { Coefficients }\end{array} \\
\text { Beta }\end{array}$} & \multirow[t]{2}{*}{$\mathrm{t}$} & \multirow[t]{2}{*}{ Sig } \\
\hline & & B & Std. Error & & & \\
\hline \multirow[t]{4}{*}{1} & (Constant) & 10.910 & 8.647 & & 2.765 & .008 \\
\hline & Company Costs & .0 .6155 & .137 & .155 & 1.136 & .261 \\
\hline & Division of Labor & 0.1910 & .129 & .193 & 1.489 & .143 \\
\hline & $\begin{array}{l}\text { Organizational } \\
\text { structure }\end{array}$ & 0.4020 & .160 & .344 & 2.515 & .015 \\
\hline
\end{tabular}

Source: processed data

Table 6. shows the constant value of 10.910 , job culture coefficient 0.6155 , division of labor coefficient 0.1910 , organizational structure coefficient 0.4020 . Thus, the mathematical equation becomes $\mathrm{Y}=10.910+0.6155 \mathrm{X} 1+0.1910 \mathrm{X} 2+0.402 \mathrm{X} 3$.

Note X1 corporate culture variable; X2 division of labour variable; X3 organizational structure variables; and $\mathrm{Y}$ employee job performance variables.

Multiple regression analysis as follows:

a. The constant value is 10,910 which states that if the corporate culture variable (X1), the division of labour (X2), the organizational structure (X3) is considered constant, the average job performance is 10,910 units.

b. The job culture regression coefficient is 0.6155 which states that each addition of one of the corporate culture unit will increase the employee's job performance by 0.6155 units.

c. The division of labour regression coefficient which is 0.1910 states that each addition of one division of labour unit will increase the employee's job performance by 0.1910 units.

d. The organizational structure regression coefficient is 0.4020 which states that each addition of one organizational structure unit will increase the employee's job performance by 0.4020 units.

Test F

Table 7. Result of Test F 


\begin{tabular}{|c|l|c|c|c|c|c|}
\hline \multicolumn{2}{|c|}{ Model } & $\begin{array}{c}\text { Sum of } \\
\text { Squares }\end{array}$ & df & $\begin{array}{c}\text { Mean } \\
\text { Square }\end{array}$ & F & Sig. \\
\hline \multirow{2}{*}{1} & $\begin{array}{l}\text { Regressio } \\
\mathrm{n}\end{array}$ & 70.346 & 3 & 23.449 & 2.971 & $.040^{\mathrm{b}}$ \\
\cline { 2 - 7 } & Residual & 402.563 & 51 & 7.893 & & \\
\cline { 2 - 7 } & Total & 472.909 & 54 & & & \\
\hline
\end{tabular}

Source: processed data

Table 7 shows the results of the test for the $\mathrm{F}$ value of 2.97, with a significance level of $\alpha=$ 0.05 or $5 \%$, Degree of Freedom (df) numerator $=k-1=4-1=3$ and $\mathrm{df}=\mathrm{n}-\mathrm{k}=124-3=$ 121 so that the value of $\mathrm{F}$ table $=2.68$, then the value of $\mathrm{F}$ count, $2.971>$ from $\mathrm{F}$ table 2.680, thus the regression model can be used to predict job performance or corporate culture, division of labour and organizational structure jointly affect job performance.

The hypothesis used is:

Ho $=$ There is no influence on corporate culture, division of labour, and organizational structure on the employee job performance of PT.XYZ

$\mathrm{Ha}=$ There is an influence of company culture, division of labour, and organizational structure on the employee job performance of PT.XYZ

Conclusion: the calculated $\mathrm{F}$ value is greater than $\mathrm{F}$ table or $2.971>2.68$ so that Ho is rejected and $\mathrm{Ha}$ is accepted, there is an influence of corporate culture, division of labour, organizational structure simultaneously on the employee job performance of PT.XYZ.

The simultaneous test results are described in the form of a sampling distribution curve as follows:

Figure 3. Simultaneous Test Results

\section{Curve}

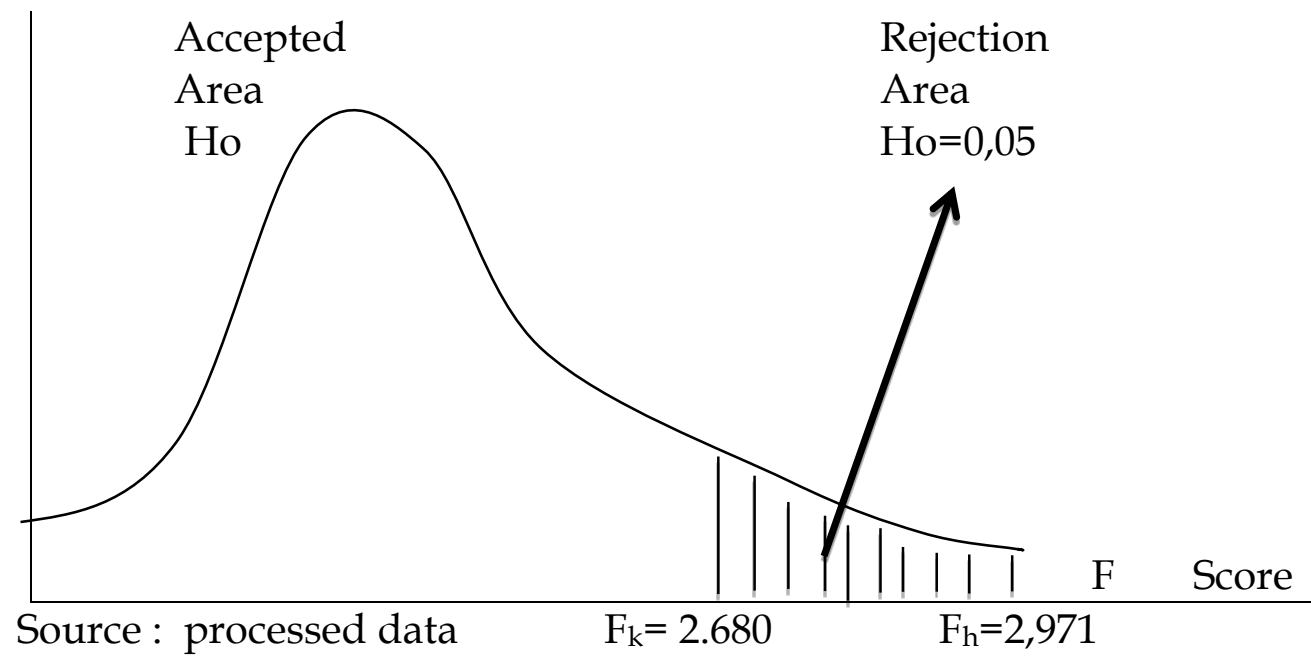

Figure 3. shows the curve above with the value of $F h=2.971$ in the rejection area Ho or Fh> Fk, 2.971>2.680 means that Ho is rejected and Ha is accepted. Thus, there is a simultaneous 
PRIMANOMICS : JURNAL EKONOMI DAN BISNIS - VOL. 19. No. 1 (2021)

Versi Online Tersedia di : https://jurnal.ubd.ac.id/index.php/ds

| 1412-632X (Cetak) | 2614-6789 (Online) |

influence of corporate culture, division of labour and organizational structure on employee performance at PT XYZ.

\section{DISCUSSION}

The results of the analysis and testing found that the questions or the variables in this study were all valid as shown in table 1 . The test results obtained $r$ count $>\mathrm{r}$ critical, which is the average above 0.30 . Likewise, the results of the reliability test on the questionnaire obtained the Cronbach's alpha coefficient value above the required value of 0.60 as shown in table 2. Therefore, all questionnaires were reliable. The data normality test is shown in graph 1. Normal Plot is seen at the points that spread evenly and the distribution follows the direction of the diagonal line. So, the two graphs show that the regression model is feasible because it meets the assumption of normality. The multicollinearity test in table 3 shows the test results, the tolerance value $<0.10$ and the VIF value $>10$, it can be concluded that there is no multicollinearity between the independent variables in the regression model. The heteroscedasticity test in graph 2 shows that the points spread randomly and are evenly distributed above and below the number 0 on the Y-axis and do not have a clear pattern or form a pattern. Thus, it is concluded that there is no heteroscedasticity in the regression model, so the regression model is suitable for use as a prediction. The test results of the coefficient of determination in table 5 are shown in the results of $R=0.546$. This means that the variables of corporate culture, division of labour and organizational structure can be predictors of job performance variables of $54.6 \%$ and the remaining $45.4 \%$ is influenced by other factors that have not been studied. The results of multiple regression testing in Table 6 show a constant value of 10,910 which states that if the corporate culture variable (X1), the division of labour $(X 2)$, the organizational structure $(X 3)$ is considered constant, the average job performance is 10,910 units. The corporate culture regression coefficient of 0.6155 states that each addition of one unit of corporate culture can increase an employee's job performance by 0.6155 units. The division of labour regression coefficient of 0.1910 states that each addition of one division of labour can increase the job performance of its employees by 0.1910 units. The organizational structure regression coefficient of 0.4020 states that each addition of one organizational structure unit can increase an employee's job performance by 0.4020 units. Simultaneous significance test results (F statistical test) table 7 shows the value of $F$ count 2.97, with a significance level of $a=0.05$ or $5 \%$, Degree of Freedom (df) numerator $=\mathrm{k}-1=4-1=3$ and $\mathrm{df}=\mathrm{n}-\mathrm{k}=124-3=121$ so that the value of $\mathrm{F}$ table $=2.68$ then the value of $\mathrm{F}$ count, 2.971 $>$ from $\mathrm{F}$ table 2.680. Thus, the regression model can be used to predict job performance or corporate culture, division of labour and organizational structure jointly influence job performance. From this explanation, it is concluded that the calculated F value is greater than F table or 2,971 > 2.68 so that Ho is rejected and $\mathrm{Ha}$ is accepted, so there is a simultaneous influence of corporate culture, division of labour, and organizational structure on the job performance of PT.XYZ employees. Testing the hypothesis of the curve shape in Figure 2 shows a curve where the value of $\mathrm{Fh}=2,971$ is in the rejection area of $\mathrm{Ho}$ or $\mathrm{Fh}>\mathrm{Fk}, 2,971>2,680$ means that Ho is rejected and Ha is accepted. Thus, there is a simultaneous influence of corporate culture, division of labour and organizational structure on employee performance at PT XYZ.

\section{CONCLUSION}


The results of the study concluded that the relationship between corporate culture, division of labour and organizational structure at PT. XYZ is not too significant for job performance. However, the impact of the study is very varied, namely, the influence of corporate culture is quite significant, in contrast to the influence caused by the division of labour and organizational structure on the very insignificant company.

\section{SUGGESTION}

PT. XYZ must repair the pattern of division of labour contained in the company so that each member of the organization can maximize its role to improve job performance. Likewise, the organizational structure should be made clearer with the characteristics and types of company operations. The organizational culture shows a good enough influence so that companies need to maintain and improve employee job performance maximally

\section{References}

Atmosoeprapto (2001) Dengan Kepemimpinan Efektif dan Manajemen Efisien. Jakarta : PT. Elex Media Komputindo

Basid, R,A.,Alya,R,E. (2020). Analisis Pengaruh Elemen Subjective Well-Being terhadap Organizational Citizenship Behavior Karyawan. OPTIMAL.Jurnal Ekonomi Dan Kewirausahaan, 14(1), 1-15.

Bernardin.,Russel. (1993). Manajemen Kinerja. Bandung: PT. Remaja Rosdakarya

Gozhali,I (2012) Aplikasi Analisis Multivariate.Semarang :Badan Penerbit Universitas Diponegoro

Hadian, D. (2015). Pengaruh Kepemimpinan, Struktur Organisasi dan Budaya Organisasi terhadap Kinerja Dinas serta Implikasinya pada Pelayanan Publik. Jurnal Kontigensi, 3(1), 26-43.

Hamid, F. G. D., \& Riza, M. F. (2014). Pengaruh Struktur Organisasi terhadap Efektivitas Organisasi. Jurnal Administrasi Bisnis (JAB), 7(2), 1-10.

Hayati, N. (2020). Pengaruh Persepsi Dukungan Organisasi dan Budaya Organisasi Terhadap Organizational Citizenship Behaviour Melalui Kepuasan Kerja. Equilibrium : Jurnal Ekonomi Manajemen-Akuntansi, 16(2), 54-61.

Hakim,L.,Kusdiyanto (2012) Analisis Pengaruh Budaya Organisasi Terhadap Kinerja Karyawan (Studi Kasus PDAM Kota Surakarta).BENEFIT : Jurnal Manajemen dan Bisnis.16 (2) 53-57

Handoko,T. (2011). Manajemen, Dasar, Pengertian, dan Masalah. Jakarta: CV Haji Masagung

Jones,G.,George,J,M.(2010).Contemporary Management,Fith edition.USA : McGraw-Hill International

Kusumawardani,L.(2018). Budaya Organisasi dalam Meningkatkan Kinerja Karyawan. BISMA (Bisnis Dan Manajemen), 2(2), 159. https:// doi.org/10.26740/bisma.v2n2.p159166

Mangkuprawira. (2013). Meningkat Efektivitas Dan Efesien Perusahaan.Jakarat : Restu Agung Novziransyah, N. (2017). Pengaruh Budaya organisasi terhadap Kinerja Karyawan PT. PLN (PERSERO) Kantor Wilayah Sumatera Utara Medan. Jurnal JUMANTIK, 2(1), 13-25.

Mondy. R. Wayne,M,W.(2014). Personel Management Of Human Resourse Baston: Allen \& Bacon.

Pangastuti,S,D.,Santosa,S. (2013). Pengaruh Pendelegasian Wewenang dan Pembagian Kerja terhadap Prestasi Kerja Karyawan BTN Surakarta. JUPE UNS, 2(2), 26-36. 
PRIMANOMICS : JURNAL EKONOMI DAN BISNIS - VOL. 19. NO. 1 (2021)

Versi Online Tersedia di : https://jurnal.ubd.ac.id/index.php/ds

| 1412-632X (Cetak) | 2614-6789 (Online) |

Roring, F. (2017). Pengaruh Kepemimpinan,Pembagian Kerja dan Kompensasi Terhadap Kinerja Karyawan Pada PT.Bank Danamon Cabang Manado.JURNAL MANAJEMEN BISNIS DAN INOVASi, 4(3), 144-154.

Salam, R., Yunus, H., Akib, H., \& Makassar, U. N. (2017). Pengaruh Budaya Organisasi terhadap Kinerja Pegawai pada Dinas Pendidikan Provinsi Sulawesi Selatan. Jurnal Ad'ministrare: Jurnal Pemikiran Ilmiah Dan Pendidikan Administrasi Perkantoran, 4(1), 2634.

Sitio, R. (2019). Analisa Fasilitas Kerja, Pelatihan dan Kedisiplinan Terhadap Kinerja Karyawan PT. Centrayasa Megatamacipta. ECo-Buss, 2(1), 53-60. https:/ / doi.org/10.32877/eb.v2i1.99

Sitio, R. (2020). Kajian Disiplin dan Motivasi Kerja terhadap Kinerja Karyawan (Studi Kasus Hotel Ibis Styles Gajah Mada Jakarta). Journal of Technopreneurship on Economics and Business Review, 1(1), 69-78.

Sitio,R., Dessy,M. (2020). Sikap sosial, ekonomi masyarakat kampung bandan, terhadap, perawatan dan kebersihan,fasilitas mck. MPU PROCURATIO, 2(April), 319324

Sulastri, T. (2007). Hubungan Motivasi Berprestasi Dan Disiplin Dengan Kinerja Dosen. Jurnal Fakultas Ekonomi: OPTIMAL, 1(1), 13-21.

Sugiyono.(2014)Metode Penelitian.Bandung : Alfabeta

Sunarsi,D.,Yuliani,I. (2019). Pengaruh Gaya Kepemimpinan dan Budaya Organisasi Terhadap Kinerja Karyawan Pada Bank BTN Kantor Cabang Pembantu Tanggerang. Jurnal Semarak, 2(1), 21-31.

Tae,A,M.,Rahmat,L, M. (2019). Pengaruh Penerapan Total Quality Management Terhadap Kinerja Karyawan. Jurnal Manajemen, 3(2), 42-50.

Thea,H,R.,Purwanto,P. (2017). Organisasi pembelajaran, kompetensi dan kinerja karyawan bank xxx di jakarta. Jurnal Muara Ilmu Ekonomi Dan Bisnis, 1(2), 136-151.

Trang, D. S. (2013). Gaya Kepemimpinan dan Budaya Organisasi Pengaruhnya Terhadap Kinerja Karyawan. (Studi pada Perwakilan BPKP Provinsi Sulawesi Utara). Jurnal EMBA, 1(3), 208-216.

Umar,H.(2008).Metode Penelitian Untuk Skripsi Dan Tesis.Jakarta : PT.Raja Grafindo Persada

Usdarisman.,Erpidawati (2020) Analisis Pengaruh Gaya Kepemimpinan Demokratis dan Motivasi Kerja Terhadap Disiplin Kerja Guru di SD Negeri Kecamatan Kuranji Kota Padang. PRODU: Prokurasi Edukasi Jurnal Manajemen Pendidikan Islam.2(1) 28-37

Vilani, M., Wiedy, Murtini., Anton, S. (2019). Pengaruh Budaya Kerja dan Pembagian Kerja Terhadap Kinerja Pegawai di FKIP UNS (Studi Eksplanasi). Jurnal IKRA-ITH Ekonomika, 2(3), 76-84.

Wahyudi,W,W.,Tupti,Z (2019). Pengaruh Budaya Organisasi, Motivasi dan Kepuasan Kerja Terhadap Kinerja Pegawai. Maneggio: Jurnal Ilmiah Magister Manajemen Vol, 2(1), 31-44. 